\title{
SALES VERSUS INCOME TAXES: THE ISSUES OF ADEQUACY IN TENNESSEE
}

\author{
Robert A. Bohm and Samuel R. Carter*
}

\section{Introduction}

In the literature on state and local taxation, the concept of adequacy is normally defined as the ability of a tax or tax system to provide for revenue growth that keeps pace with the growth of the local economy without the need for continued modification of tax rates or tax bases. ${ }^{1}$ For most states, adequacy has been an elusive standard of performance either due to over reliance on income inelastic commodity based consumption taxes or a mismatch between tax system emphasis and sources of economic growth (Weidenbaum, 1967). Public fiscal affairs in Tennessee are a prime example of this phenomena where recurring fiscal crises have been manifest in budget impoundments, service cutbacks, increased tax rates and expanded tax bases, searches for new sources of revenue, and a growing desire for tax reform (Hood, 1982; Lyons, 1982; McGrory, 1982).

This study evaluates the adequacy of the Tennessee tax system. For Tennessee, this problem is essentially a study of the state sales and use tax, as this tax dominates the state revenue system. In the following section, the concept of adequacy is further defined, and general data on the existing Tennessee tax system are presented. The third section contains an empirical model of the Tennessee sales tax, while in the fourth section is presented an alternative tax structure for the state is presented which includes both a sales tax and an income tax. Revenue simulations presented in this section clearly demonstrate the superiority of the alternative system on adequacy grounds.
Adequacy and the Tenneseee Structure

\section{The Adequacy Criterion}

The notion of adequacy used in this paper is derived from the work of Wilford (1965), Legler and Shapiro (1968) and Fox (1984). It is understood as a long run concept and is essentially equivalent with tax responsiveness. Thus taxes that exhibit revenue elasticities with respect to population or income growth in a state that are greater than one are generally considered adequate taxes, i.e., revenues will tend to increase (and contract) along with changes in economic conditions.

Concern over the adequacy of state and local tax systems is a relatively recent phenomena dating from the seminal work of Groves and Kahn (1952). During the 1960s, the recognition that the demand for state services was growing at a pace far in excess of that of traditional financial resources added a sense of urgency to the search for adequate tax instruments and structures (Hirsch, 1970). In the South, this factor was exacerbated in the 1970s by the rapid economic expansion of the states lying in the so-called sunbelt.

As an illustration of the problem faced by Tennessee, consider the fact that during the 1970-80 period the rate and base of the state sales tax had to be modified six times (Biennial Report, 1982). This suggests that the Tennessee tax system was insufficient to meet expenditure demands during a period characterized by sizable federal to state intergovernmental transfers. Tennessee is a state with historically low per capita outlays in most expenditure categories. Its current tax system creates a politically charged situation which calls for almost continual consideration of the need for spending cuts versus the need for continued piecemeal (or alternatively complete) revision of its tax system.

\section{The Tennessee Tax Structure}

Table 1 summarizes the existing distribution of tax revenue in Tennessee. All corporation
*Professor of Economics, The University of Tennessee and Marketing Representative, IBM Corporation. 
Table 1

\begin{tabular}{lr}
\multicolumn{2}{c}{$\begin{array}{c}\text { Sources of Tennessee } \\
\text { Tax Revenue: 1981-1982 }\end{array}$} \\
\hline \multicolumn{1}{c}{ Tax } & $\begin{array}{c}\text { Percent of } \\
\text { Total Revenue }\end{array}$ \\
\hline Sales and Use & 52.2 \\
Motor Vehicle Fuel & 13.2 \\
Corporate & 12.0 \\
Selective Sales & 7.6 \\
Motor Vehicle Registrations & 6.1 \\
Tobacco & 3.7 \\
Alcoholic Products & 2.7 \\
Hall Income & 2.1 \\
Inheritance & 1.3 \\
\hline \hline
\end{tabular}

Source: Biennial Report, 1982.

taxes, including the corporate excise (i.e., income) tax and several smaller levies, have been grouped together. The selective sales taxes include the state gross receipts tax, privilege tax, and business tax. The Hall Income Tax is a narrow-based tax restricted to dividend and interest income.

Two overriding factors should be apparent from Table 1. First, unlike 44 other states, Tennessee has no general individual income tax. In the South, Tennessee is the only state without an individual income tax that cannot generate substantial revenues from a significant specialized tax base (i.e., severence taxes in Texas and Louisiana, tourism and the retirement community in Florida). The second factor is that Tennessee tax revenue is derived almost exclusively from sales-type taxes with one tax, the sales and use tax (i.e. sales tax), providing over 50 percent of all tax revenue. Since its inception in 1947 at a rate of 2.0 percent, the sales tax base has been modified on 10 different occasions. The rate has been raised three times: from 2.0 percent to 3.0 percent in 1956 , from 3.0 percent to 3.5 percent in 1972 and from 3.5 percent to 4.5 percent in $1976 .{ }^{2}$

\section{A Model of the Tennessee Sales and Use Tax}

The purpose of this section is to specify and estimate a revenue model of the Tennessee sales and use tax. Since the early work of Groves and Kahn (1952), the specification of revenue models has improved considerably. Today it is generally recognized that revenues respond to income per capita, population and tax rates. Still, the specification and estimation of revenue models can be improved fur- ther. The importance of prices and the expectation of inflation can not be denied following the experience of the late 1970s and early 1980s. In addition, factors that are pertinent to only one tax, one state, or one time period should not be ignored.

\section{Estimation Methodology and Data Sources}

Single equation models of individual taxes are rich sources of information on the determinants of revenue on a case by case basis. However, these models do not incorporate system effects on revenue generated by a given tax. Nor can they be used to evaluate the adequacy of the tax system.

To achieve the goal of designing a tax system that can be termed adequate, a complete system model is required. The value of such a model is that the responsiveness of a single or group of similar taxes to such factors as income and population can be judged independently but with the knowledge that system interactions are incorporated into the estimates. Carter (1984) has estimated such a multiequation tax revenue model for Tennessee. The results for the sales tax reported below utilize this broader model to incorporate system effects.

For purposes of estimation, comparable data on all variables can be obtained for the years 1950 to $1980 .^{3}$ All continuous variables have been converted to natural logarithmic form prior to making calculations. Three estimates are presented: an ordinary least squares estimate (OLS), an estimate corrected for autocorrelation (AUTOREG), and a seemingly unrelated regressions estimate (SUR).

\section{A Sales and Use Tax Model}

Income per capita, and population are the variables that permit a judgement on revenue adequacy. These variables are the appropriate proxies for missing information on the specific tax bases. In effect, broad measures of economic activity are substituted for detailed measures of economic activity. Revenues will always be expected to respond positively to these income and population variables, with the key determinant of adequacy being their respective elasticities. Since both income per capita and population are increasing in Tennessee, there is a possibility of dual criteria, i.e. an adequate tax could be said to 
respond to both. At a minimum, a tax should be responsive to either population or income per capita. In all cases, responsiveness will be defined as an elasticity greater than one.

Several other variables are incorporated into the model in an attempt to improve the specification. During the decade 1970-1980, inflation began to have a significant impact on Tennessee tax revenues. The aspect which needs to be represented in the sales tax equation is the effect of inflationary expectations on purchases. The hypothesis here is that anticipation of higher prices in the future will lead to increased spending (and hence higher sales tax revenue) today. Expectations are often based on recent experience, so the empirical specification of this variable is the change in the GNP deflator in the previous year (Aaron, 1976).

A second factor that needs representation is the development of credit, particularly consumer credit, in Tennessee and the South during the period under study. The effect of this factor is to allow present purchases to be financed out of future incomes and profits. As a result, the annual ratio of consumption to income can be inflated for short periods leading to higher sales tax revenue collections. The variable used to reflect credit growth is per capita loans to individuals in the state. A final set of variables includes the 10 adjustments and alterations to the sales tax base over the period. Each has been included as a zero/one dummy variable, however, preliminary results indicated that only the exclusion of government services in $\mathbf{1 9 5 5}$ had a significant effect on revenues.

The final specification of the sales tax revenue equation is:

$$
\begin{gathered}
\text { ST }= \\
\text { CRCY, POPUL, STR, INFLEXP, } \\
\text { CREDIT, GOVT) }
\end{gathered}
$$

where

$\begin{array}{ll}\text { ST }= & \text { annual revenue from } \\ & \text { sales and use tax } \\ \text { PCY } & \text { per capita income } \\ \text { POPUL } & \text { population } \\ \text { STR } & \text { sales and use tax rate } \\ \text { INFLEXP = } & \text { change in the GNP } \\ & \text { deflator } \\ \text { CREDIT = } & \text { per capita loans to in- } \\ & \text { dividuals } \\ \text { GOVT } & \text { dummy for exclusion of } \\ & \text { government services } \\ & \text { from tax base (one for } \\ & \text { the years 1955-1980; } \\ & \text { zero otherwise). }\end{array}$

Table 2

Sales and Use Tax Equation: Parameter Estimates

\begin{tabular}{lccc}
\hline \hline Variable & OLS & AUTOREG & SUR \\
\hline PCY & $0.518629^{*}$ & $0.491615^{*}$ & $0.466915^{*}$ \\
& $(0.113771)$ & $(0.141201)$ & $(0.092586)$ \\
POPUL & $1.900562^{*}$ & $2.046016^{*}$ & $1.8979226^{*}$ \\
STR & $(0.597767)$ & $(0.754970)$ & $(0.477949)$ \\
& $0.929053^{*}$ & $0.938211^{*}$ & $0.941170^{*}$ \\
INFLEXP & $(0.075082)$ & $(0.071058)$ & $(0.054847)$ \\
& $0.047504^{*}$ & $0.039948^{*}$ & $0.069448^{*}$ \\
CREDIT & $(0.016155)$ & $(0.015024)$ & $(0.014266)$ \\
& $0.257098^{*}$ & $0.257582^{*}$ & $0.270204^{*}$ \\
GOVT & $(0.066190)$ & $(0.076935)$ & $(0.053583)$ \\
& $-0.083915^{* *}$ & $-0.074077^{* *}$ & -0.067154 \\
Intercept & $(0.032744)$ & $(0.030346)$ & $(0.025018)$ \\
R2 & $-15.127656^{*}$ & $-16.135594^{*}$ & $-14.592142^{*}$ \\
DW & $(4.577731)$ & $(5.629044)$ & $(3.65172)$ \\
\hline
\end{tabular}

*Denotes significance of error of 0.01 or better.

**Denotes significance of error of 0.05 or better.

nDenotes not reported.

IDenotes inconclusive Durbin-Watson Test.

Note: Numbers in parentheses are standard errors of the estimates. 
The OLS, AUTOREG, and SUR estimates of the sales tax equation are presented in Table 2. Note that there appears to be little difference between the OLS, AUTOREG and SUR estimates.

The results presented in Table 2 clearly indicate the nature and the problems of the Tennessee sales and use tax. Revenues respond well to population, however, population in the state has only been on a noticeable upswing during the 1970-1980 decade. Thus, for most of the period under study, adequacy for this tax (and therefore essentially for the entire Tennessee tax system) would have to rely on responsiveness to the growth in income. In this regard, the sales tax has performed miserably with an elasticity of revenue with respect to per capita income of 0.47 in the SUR column of Table 2. With estimated income elasticities for most state government services at 1.0 or greater (Musgrave and Musgrave, 1984), the basis for expecting continued fiscal stress is clear. Fortunately for the state, rate changes have been effective in raising revenue with coefficients for this variable near 1.0. Substantial substitution effects away from taxed items do not appear to have taken place in Tennessee, at least during the period under study.

Both the inflationary expectations and credit availability variables are statistically significant and of the correct sign. These results support the hypothesis that inflation and the growth of money markets in the state have altered the time path of purchases. Finally, the dummy variables for the exclusion of government services from the tax base has the expected negative influence on revenue.

These results suggest that the Tennessee sales tax provides adequate responsiveness to changes in population but not to changes in income. Improvement of the adequacy of the Tennessee tax system should be in the direction of improving the responsiveness to per capita income. Such an objective can be reached in two ways. First, existing taxes can be modified albeit at the risk of losing responsiveness to population changes. A more reasonable approach would be to introduce new taxes that are more responsive to income changes and attempt to achieve a balance between income elastic and population elastic taxes.

\section{A Tennessee Income Tax}

\section{Federal Income Tax Definitions}

The purpose of this section is to investigate the implications of instituting a flat rate income tax in Tennessee based on federal income tax definitions. Although it is possible for Tennessee to construct an independent income tax system, it is far simpler administratively to employ the structure already in place at the federal level. The state has three alternatives on which to base a definition of state taxable income: ${ }^{4}$

1. Federal Adjusted Gross Income

2. Federally Defined Taxable Income

3. Federal Income Tax Obligation

Utilizing either the second or third alternative immediately incorporates the progressivity of the federal system resulting from its adjustments, deductions, and exemptions. The third alternative incorporates the federal tax rate structure as well. Federal Adjusted Gross Income would be the most inclusive concept as it precedes the computation of deductions and exemptions in the federal system.

Tennessee could adopt either of these three definitions directly or modify them. For example, if adjusted gross income is selected, some family based allowance may be desirable. ${ }^{5}$ Still, it would again appear simpler administratively to choose among the three on the basis of state objectives with regard to the degree of progressivity and comprehensiveness desired and apply a flat rate to the base chosen.

\section{Adequacy Considerations}

One method of improving the overall adequacy of the Tennessee tax system is through the introduction of a tax that is reponsive to per capita income. Revenues based on each income definition have been regressed against state per capita income alone and state per capita income and population in double log transformation (Carter, 1984). After corrections for autocorrelation, it appears that either federal taxable income or the federal tax obligation would provide the greatest amount of responsiveness with income elasticities in the 1.4 range. $^{6}$

\section{Income Tax Versus Sales Tax}

The purpose of this section is to explore the 
trade-off between the historical case of increasing reliance on the sales tax and a combined income tax-sales tax system. In the simulations to follow, the years 1972 an 1976 (both years when the sales tax rate was increased significantly) are used as points of departure. The objective of the simulations is to compare actual sales tax revenue in 1980 with estimates of revenue from a modified system that includes both a sales tax and an income tax.

Results of the simulations are reported in Tables 3 and 4. Table 3 reports the results of the experiment assuming that federal taxable income is used as the Tennessee income tax base, while Table 4 assumes that the federal tax obligation is the base. In each table, the first two columns present data on revenues from the existing sales and use tax from 1970 to 1980 . The first column includes estimated collections based on the sales and use tax equation estimated in the third section. The second column includes actual collections. (Note that the average error is about 0.21 percent.)
In columns three and four of Tables 3 and 4, it is assumed that the sales tax rate was not increased in 1972. Rather, it is assumed that it was reduced to 2.0 percent (column three) or held constant at 3.0 percent (column four). The revenue shortfall is made up by a flat rate income tax. The data shown in the columns are the projected combined revenues of both taxes assuming no further changes in rates or bases of either $\operatorname{tax}$ (e.g., the 1976 increase in the sales tax does not take place).

Columns five and six of the two tables repeat the experiment assuming it begins in 1976. The sales tax rate is dropped to either 2.0 percent or 3.0 percent rather than raising it to 4.5 percent. Flat rate income taxes are again used to eliminate the revenue shortfall in the initial year. For example, with federal taxable income as the base (Table 3), assuming the sales tax rate was dropped to 2.0 percent in 1976 , the combined sales-income tax system would have yielded an estimated 1010.54 million dollars in 1980. From column two, it can be seen that the

Table 3

Revenue Simulations Using Federal Taxable Income Base

\begin{tabular}{|c|c|c|c|c|c|c|}
\hline \multirow[b]{3}{*}{ Year } & \multicolumn{2}{|c|}{ Sales Tax Revenue } & \multicolumn{4}{|c|}{ Estimated Total Sales \& Income Tax Revenue } \\
\hline & \multirow[b]{2}{*}{ Estimated } & \multirow[b]{2}{*}{ Actual } & \multicolumn{2}{|c|}{1972 Change } & \multicolumn{2}{|c|}{1976 Change } \\
\hline & & & $2 \%$ Rate & $3 \%$ Rate & $2 \%$ Rate & 3\% Rate \\
\hline 1970 & 241.91 & 239.19 & - & - & - & - \\
\hline 1971 & 263.46 & 262.06 & - & - & - & - \\
\hline 1972 & 343.38 & 351.86 & 353.82 & $\mathbf{3 4 9 . 3 5}$ & - & - \\
\hline 1973 & 399.29 & 399.44 & 414.53 & 403.90 & - & - \\
\hline 1974 & 446.91 & 447.29 & 466.95 & 454.55 & - & - \\
\hline 1975 & 482.97 & 474.57 & 495.84 & 488.86 & - & - \\
\hline 1976 & 551.34 & 554.00 & 549.50 & 532.64 & 611.35 & 590.73 \\
\hline 1977 & 724.02 & 730.67 & 675.87 & 610.32 & 737.19 & 740.63 \\
\hline 1978 & 818.32 & 831.33 & 776.99 & 692.34 & 848.99 & 845.34 \\
\hline 1979 & 918.99 & 938.66 & 845.56 & 765.95 & 921.89 & 928.15 \\
\hline 1980 & 997.70 & 978.12 & 925.86 & 831.88 & 1010.54 & 1011.83 \\
\hline
\end{tabular}

Table 4

Revenue Simulations Using Federal Tax Obligntion Base

\begin{tabular}{|c|c|c|c|c|c|c|}
\hline \multirow[b]{3}{*}{ Year } & \multicolumn{2}{|c|}{ Sales Tax Revenue } & \multicolumn{4}{|c|}{ Estimated Total Sales \& Income Tax Revenue } \\
\hline & \multirow[b]{2}{*}{ Estimated } & \multirow[b]{2}{*}{ Actual } & \multicolumn{2}{|c|}{1972 Change } & \multicolumn{2}{|c|}{1976 Change } \\
\hline & & & $2 \%$ Rate & $3 \%$ Rate & $2 \%$ Rate & $3 \%$ Rate \\
\hline 1970 & 241.91 & 239.19 & - & - & - & - \\
\hline 1971 & 263.46 & 262.06 & - & - & - & - \\
\hline 1972 & 343.38 & 351.86 & 352.43 & 351.19 & - & - \\
\hline 1973 & 399.29 & 399.44 & 408.27 & 404.47 & - & - \\
\hline 1974 & 446.91 & 447.29 & 460.30 & 455.34 & - & - \\
\hline 1975 & 482.97 & 474.57 & 481.80 & 487.13 & - & - \\
\hline 1976 & 551.34 & 554.00 & 532.59 & 530.36 & 635.46 & 603.00 \\
\hline 1977 & 724.02 & 730.67 & 604.54 & 590.13 & 730.93 & 732.32 \\
\hline 1978 & 818.32 & 831.33 & 682.37 & 664.76 & 825.60 & 825.90 \\
\hline 1979 & 918.99 & 938.66 & 758.65 & 741.49 & 916.86 & 919.47 \\
\hline 1980 & 997.70 & 978.12 & 853.22 & 813.22 & 1040.03 & 1023.39 \\
\hline
\end{tabular}


Table 5

Income Tax Rates Required to Replace Sales Tax Revenues

\begin{tabular}{|c|c|c|}
\hline \multirow[t]{2}{*}{ Case } & \multicolumn{2}{|c|}{ Income Tax Rates } \\
\hline & $\begin{array}{l}\text { Federal Taxable } \\
\text { Income Base }\end{array}$ & $\begin{array}{c}\text { Federal Tax } \\
\text { Obligation Base }\end{array}$ \\
\hline $\begin{array}{l}1972 \text { Case: } \\
\text { Sales Tax Rate }=2.0 \% \\
\text { Sales Tax Rate }=3.0 \%\end{array}$ & $\begin{array}{l}2.20 \% \\
0.75 \%\end{array}$ & $\begin{array}{r}10.1 \% \\
6.2 \%\end{array}$ \\
\hline $\begin{array}{l}1976 \text { Case: } \\
\text { Sales Tax Rate }=2.0 \% \\
\text { Sales Tax Rate }=3.0 \%\end{array}$ & $\begin{array}{l}2.60 \% \\
1.60 \%\end{array}$ & $\begin{array}{r}14.9 \% \\
9.0 \%\end{array}$ \\
\hline
\end{tabular}

4.5 percent sales tax yielded 978.12 million dollars. Table 5 presents a list of the income tax rates required in either 1972 or 1976 to produce the revenue lost by reducing or not increasing the sales tax rate.

The results of the simulation are clear. Turning to an income tax in 1972 could have produced a tax system featuring low rates on both sales and income tax. With no changes since 1972, estimated revenues are only slightly below actual sales tax collections. If the income tax were incorporated in 1976, estimated revenue collections of the combined system are actually ahead of actual sales tax collections. This evidence seems sufficient to declare that a Tennessee tax system based on both an income tax and a sales tax would have proven more adequate than the sales tax only system. Furthermore, if needs for more revenue arise, the combined system presents a much wider range of untapped potential.

The final choice of base (federal taxable income or federal tax obligation) does not affect the conclusion. Thus, this determination can be made on other grounds such as equity, economic efficiency, or administration. In addition, the presence of an income tax in the system provides other possibilities for making changes in the system (e.g., credits for food purchases covered by the sales tax).

\section{Conclusion}

During the winter of 1984 , the Tennessee legislature and governor raised the state sales tax rate to 5.5 percent and further expanded the base to include amusements. When combined with the existing local option sales tax, the overall rate approaches 8.0 percent. The need for revenue to support education was a major impetus for adjusting the sales tax rate and base. Recent history suggests that the basic inadequacy of the sales tax will lead to renewed fiscal difficulties in the near future. ${ }^{7}$

This study has shown that the recurring problem of poor responsiveness of tax revenues to economic growth can be overcome through the introduction of a flat rate income tax, based either on federal taxable income or the federal income tax obligation. A tax system which includes both the current sales tax and the proposed income tax would be responsive to both income and population growth. Revenues produced by relatively low rates would be comparable to those generated now by a sales tax with a very high rate.

The proposed two base system will place Tennessee in a much better position to weather the fiscal stresses of the 1980s. Although not covered in this study, a revision of tax system emphasis to a combined income tax/sales tax approach should also provide spillover benefits in the areas of equity, efficiency and administration (Carter, 1984).

\section{FOOTNOTES}

\footnotetext{
'To be precise, the linkage of tax revenue to economic growth should include the intermediate step of expenditure demands. Note also that one might prefer to argue that inadequate tax systems are preferable because they force state legislatures to be more judicious in their development of spending plans.

'The history of the Tennessee sales and use tax is discussed by Carter (1984).

'Data sources are fully documented in Carter (1984).

The definition of income for the federal income tax is discussed in any standard textbook in Public Finance, e.g., Musgrave and Musgrave (1984).

Any attempt to modify the federal tax base for use in Tennessee would most likely concentrate on existing tax preferences, e.g., treatment of capital gains.

'In these regressions, the population variable fails normal significance tests.

'A further base modification instituted in 1984 was the gradual elimination of the sales tax on food starting in July 1985. This major base reduction may provide the pressure necessary to foster a general overhaul of the state tax system.
} 


\section{REFERENCES}

Biennal Report. (Series) Nashville: Tennessee Department of Revenue, 1947-1982.

Carter, Samuel R., Jr. Performance and Adequacy of a State Tax System: The Case of Tennessee. Knoxville, Tennessee: Unpublished Doctoral Dissertation, 1984.

Fox, William F. and Charles Campbell. "Stability of the State Sales Tax Income Elasticity," National Tax Joumal, Vol. 37 (2), June 1984.

Groves, Harold M. and C. Harry Kahn. "The Stability of State and Local Tax Yields," American Economic Review, Vol. 42 (1), March 1952, pp. 87-102.

Hirsch, Werner Z. The Economics of State and Local Governments. New York: McGraw-Hill Book Company, 1970.

Hood, Lisa. "UT Faculty Raises Salary Beefs," The Knoxville News-Sentinel. Knoxville: 9 October 1982, p. 11.

Legler, John B. and Perry Shapiro. "The Reponsiveness of
State Tax Revenue to Economic Growth," National Tax Journal, Vol. 21 (1), March 1968, pp. 47-56.

Lyons, David. "Tax Take in State is Dismal," The Knoxville News-Sentinel. Knoxville: 9 October 1982, p. 7.

McGrory, Brian. "Fund Squeeze Hurts Colleges, Report Warns," The Knoxville News-Sentinel. Knoxville: 9 October 1982, p. 9.

Musgrave, Richard A. and Peggy B. Musgrave. Public Finance in Theory and Practice. New York: McGrawHill Book Company, 1984.

Weidenbaum, Murray L. "Innovations in State and Local Government Finance." St. Louis, Missouri: Washington University, 1967 (Institute for Urban and Regional Studies Working Paper EDA 1).

Wilford, Walton T., "State Tax Stability Criteria and the Revenue-Income Elasticity Coefficient Reconsidered," National Tax Joumal, Vol. 18 (3), September 1965, pp. 304-312. 